\title{
Role of arbuscular mycorrhizal fungi in sustainable crop production and forestry in Sri Lanka - A review
}

\author{
Madhushan KWA ${ }^{1}$ Herath BMMD $^{2}$, Karunarathna SC $^{3}$ and \\ Yapa $\mathbf{P N}^{2 *}$
}

${ }^{1}$ Department of Plant Sciences, Faculty of Agriculture, Rajarata University of Sri Lanka, Anuradhapura, Sri Lanka

${ }^{2}$ Department of Biological Sciences, Faculty of Applied Sciences, Rajarata University of Sri Lanka, Mihintale (50300), Sri Lanka

${ }^{3}$ CAS Key Laboratory for Plant Diversity and Biogeography of East Asia, Kunming Institute of Botany, Chinese Academy of Sciences, Kunming 650201, P.R. China

Madhushan KWA, Herath BMMD, Karunarathna SC, Yapa PN 2021 - Role of arbuscular mycorrhizal fungi in sustainable crop production and forestry in Sri Lanka - A review. Studies in Fungi 6(1), 437-449, Doi 10.5943/sif/6/1/33

\begin{abstract}
Mycorrhizae are symbiotic associations between a soil-borne fungus and plant root. Arbuscular mycorrhizal fungi (AMF) are the most common type of mycorrhizal associations occurring in plants. AMF can increase plant growth mainly by improving nutrient uptake and making plants resistant to several biotic and abiotic stresses. Thus, AMF could be referred to as an important biofertilizer for the crop production. However, in Sri Lankan context, seems the knowledge and use of AMF is limited, though there is a great potential of using AMF for sustainable crop production and forestry. This review provides an overview on the benefits of AMF for agriculture and forestry with the studies that have been carried out to attain them, in Sri Lanka.
\end{abstract}

Keywords - Agriculture - Arbuscular mycorrhizae - Biofertilizer - Forestry

\section{Introduction}

The indiscriminate use of chemical fertilizer in agricultural crop production has caused adverse effects on the soil productivity and environmental quality throughout the world. However, the human needs should be satisfied with conserving natural resources and maintaining or improving the quality of the environment (Bagyaraj 2014). Therefore, the use of biofertilizer for soil fertility management is currently trended in sustainable farming due to their beneficial effects on the soil, plants, animals and human health. Among the microorganisms used in biofertilizer, arbuscular mycorrhizal fungi (AMF) are important candidates and recommended for sustainable agriculture (Goltapeh et al. 2008, Bagyaraj 2014, Sadhana 2014).

The conservation of prevailing forest cover and restoration of degraded forests have become necessary in worldwide. In these processes, re-establishment of soil microbes also crucial while considering the aboveground vegetation (Edirisinghe \& Madawala 2017), as they ensure the resilience of the restored ecosystem (Wardle et al. 2004). Arbuscular mycorrhizal fungi are important group of soil microorganisms and several studies have addressed their contribution in the restoration of ecosystems (Lakmali et al. 2019). Therefore, AMF could be used as tools for sustainable forest management. 
Mycorrhizae are the symbiotic associations between a soilborne fungus and the roots of a plant. The Greek term 'mycorrhiza', which literally means 'fungus roots', was first introduced by Albert Bernard Frank in 1885 (Siddiqui \& Pichtel 2008). Since this association is mutualistic, each organism gets benefitted; the fungus is provided with carbon by the host plant and in return they increase the ability of water and nutrient acquisition from the soil through extending the root surface area (Entry et al. 1999, Harrier \& Watson 2004, Smith \& Read 2010). It is estimated that $86 \%$ of all angiosperms are mycorrhizal; most abundant in terrestrial ecosystems except saline, extremely cold or disturbed habitats (Brundrett 2009, van der Heijden et al. 2015). Also, the fossil and molecular evidences have been proven that the land colonization of first plants would not possible without mycorrhizae (Fortin et al. 2009). Further, hosting of mycorrhizae is much more energy effective to the plant than producing plant roots (Marshall \& Perry 1987)

There are three main types of mycorrhizae namely, ectomycorrhizae, endomycorrhizae and ectendomycorrhizae (Brundrett 2004). Arbuscular mycorrhizal fungi, a type of endomycorrhizae is the most common type of mycorrhizal association occurring in crops and have several important applications in agriculture (Brundrett 2009). Hence, this review will focus on the AMF, with concerning their applications in agricultural crop production and forestry mainly based on findings in Sri Lanka.

\section{Arbuscular Mycorrhizal Fungi (AMF)}

Arbuscular mycorrhizae, including the fungi belonging to the Phylum Glomeromycota (Schüßler et al. 2001), and are probably the ancestral form of mycorrhizae (Wang \& Qiu 2006). Generally, AMF are regarded as obligate symbiotic biotrophs, as they cannot complete life cycle without a host plant supplying them with carbohydrates (glucose and sucrose) (Muchovej 2001, Harrison 2005, Hamel \& Plenchette 2007, Martin et al. 2007, Goltapeh et al. 2008). It is reported that AMF form symbiotic associations with $80 \%$ of terrestrial plants such as trees, shrubs, forbs and grasses (Gregory 2006).

The name 'AMF' derived as these fungi form characteristic finely branched hyphal structures, termed arbuscules, within cortical cells of plant roots (Douds \& Millner 1999). The arbuscules may act as nutrient organs (or sites of nutrient exchange among symbionts) and important for fungal multiplication (Muchovej 2001, Gregory 2006). Also, some fungal species form terminal, globose, lipid rich structures, termed vesicles, inside the root cortex, with the storage function (Strullu et al. 1983, Peterson et al. 2004, Johnson \& Gehring 2007). There are three families of AMF (Morton \& Benny 1990, Morton \& Bentivenga 1994); out of them, family Gigasporaceae (Genera Gigaspora and Scutellospora) produce only arbuscules, while Acaulosporaceae (Acaulospora and Entrophospora) and Glomaceae (Glomus and Sclerocystis) produce both arbuscules and vesicles (Douds \& Millner 1999). Hence, formerly these associations had known as vesicular-arbuscular mycorrhizal (VAM) fungi (Martin et al. 2007). The criteria for identifying AMF in roots is the presence of these arbuscules and vesicles (Hayman 1983). However, after series of AMF classification, genera of Dentiscutata, Cetrospora, Racocerta also groped in the Family Gigasporaceae (Oehl et al. 2008, Morton \& Msiska 2010).

Table 1 AMF species/genera reported in plants and different ecosystems in Sri Lanka

\begin{tabular}{lll}
\hline Plant/Ecosystem & Identified Genera/Species & Reference \\
\hline Tea & Acaulospora, Glomus, Gigaspora & Balasuriya et al. (1991) \\
Coconut & Glomus spp. & Karunasinghe et al. (2009) \\
Rubber & Gigaspora margarita, Glomus & Jayaratne et al. (1984), Jayaratna et \\
& fasciculatum & al. (1986) \\
Pepper & Glomus mosseae, (now named as & Mala et al. (2010), Kodithuwakku et \\
& Funneliformis mosseae) Glomus spp. & $\begin{array}{l}\text { al. (2016), Weerawardena \& } \\
\text { Bandara (2018) } \\
\text { Up country vegetables (Leeks, }\end{array}$ \\
Carrot and Lettuce) & Glomus sinuosum, Glomus etunicatum & Rajapaksha \& Ranasinghe (2007) \\
\hline
\end{tabular}


Table 1 Continued.

\begin{tabular}{lll}
\hline Plant/Ecosystem & Identified Genera/Species & Reference \\
\hline $\begin{array}{l}\text { Pennisetum ploystechyon } \\
\text { L. and Puraria phaseoloides }\end{array}$ & Glomus fasciculatum & Pathiratna et al. (1990) \\
Natural forests & $\begin{array}{l}\text { Glomus, Acaulaspora, Gigaspora, } \\
\text { Scutellospora }\end{array}$ & Edirisinghe \& Madawala (2017), \\
& & Mafaziya et al. (2019), \\
& Mafaziya \& Madawala (2015) \\
Eucalyptus plantation & Glomus, Acaulaspora, Gigaspora & Edirisinghe \& Madawala (2017) \\
Restored Pinus stand & Glomus, Gigaspora & Mafaziya \& Madawala (2015) \\
Degraded grassland & Glomus, Acaulaspora, Scutellospora & Mafaziya \& Madawala (2015) \\
\hline
\end{tabular}

These mutualistic soil fungi usually promote plant growth, increase nutrient uptake, ameliorate toxic soil effects, control root pest and diseases, and improve water usage and soil fertility (Halim 2009). Also, AMF influencing plant growth by binding soil particles into stable aggregates and improving soil texture and making the soil resistant to wind and erosion (Mafaziya \& Madawala 2015, Lakmali et al. 2019).

\section{Arbuscular mycorrhizal fungi in plant nutrition}

In AMF associations, the fungus extends the root system via colonizing host plant's root hairs by entering into the cortex cells (Douds \& Millner 1999, Muchovej 2001). The fungal mycelium is capable of growing into the soil about $5-15 \mathrm{~cm}$ from the infected root and reaching into smaller pores than the plant's own root hairs (Brady \& Weil 2008). Thus, the interface between plants and soil environment is expanded; hence the growth and biomass accumulation of plants and yield improved mainly by mobilizing nutrients from the soil (Toro et al. 1998). Also, AMF change the soil enzyme activity and promote the plant growth particularly in the soils with low available $\mathrm{P}$ and neutral pH (Qin et al. 2020).

Studies have shown that the target crops in Sri Lanka, usually not have taken up more than $30 \%$ of added inorganic fertilizers (Seneviratne \& Kulasooriya 1994). Mycorrhizae improve the plant uptake of added inorganic fertilizer by forming a bridge between the roots and the soil. A greenhouse experiment on the influence of mycorrhizae as a substitute for inorganic fertilizer conducted by Alawathugoda \& Dahanayake (2014) in Sri Lanka and revealed that the growth and yield of tomato (Lycopersicon esculentum) and soybean (Glycine max) could be achieved as same as the recommended dose of inorganic fertilizer by the application of standard dose of AMF $(2 \mathrm{~g} / 5 \mathrm{~L}$ water) along with half of the recommended dose of inorganic fertilizer. A similar study was conducted by Dahanayake \& Alawathugoda (2016) with two traditional rice (Oryza sativa) varieties of Sri Lanka and revealed that there was no significant difference in growth parameters between the rice plants supplied with the recommended dose of inorganic fertilizer and the commercially available mycorrhizae $(2 \mathrm{~g} / 5 \mathrm{~L}$ water) along with half of the recommended dose of inorganic fertilizer, suggesting that the mycorrhizae found to be a complement for half dose of inorganic fertilizer.

However, the AMF colonization is depending on the type of fertilizer applied and the nutrient status of soil. Karunasinghe et al. (2009) who have assessed the effect of poultry manure and inorganic fertilizer on the AMF colonization in coconut (Cocos nucifera L.) revealed that the application of inorganic fertilizer decreases the AMF colonization. A negative correlation $(\mathrm{r}=-$ $0.67, p=0.045$ ) between the AMF colonization in exotic vegetables and soil available $\mathrm{P}$ was observed by Rajapaksha \& Ranasinghe (2007) in Sri Lanka, indicating that the phosphorus (P) availability is the critical factor for AMF colonization. Weerawardena \& Bandara (2018) also reported that the poor P levels in Sri Lankan soil may facilitate AMF colonization. Yapa et al. (2020) reported that the multifunctional microbial consortium in amended soil, with AMF in flooded rice soils in dry zone, Sri Lanka were capable of potentially increasing soil phosphorus. Conversely, Karunasinghe et al. (2009) observed high levels of colonization in coconut when added with poultry manure which has high levels of available $\mathrm{P}$, suggesting the increased root 
colonization could be due to the favourable conditions created by organic manure. Further, they observed soil nitrogen $(\mathrm{N})$ (ammonium $\mathrm{N}$ ) levels had a stimulatory effect on the AMF colonization. Jayaratne et al. (1984) reported that the addition of rock phosphate reduced the root colonization in Hevea seedlings. Balasuriya et al. (2000) who studied the effect of NPK fertilizer application on the natural incidence of AMF in tea (Camellia sinensis) plant roots in Sri Lanka and observed that the viable spore counts and root colonization (\%) had not significantly been affected by levels of $\mathrm{N}$ and potassium $(\mathrm{K})$, while the highest percentage of root colonization has reported when no $\mathrm{P}$ fertilizer added and the viable spore counts have significantly reduced with the increasing $\mathrm{P}$ fertilizer levels. It was also observed that no AMF colonization in the roots of maize in triple super phosphate (TSP) applied soil, in Dry zone, Sri Lanka and 25-60\% of colonization was recorded with the addition of rock phosphate (Wanninayake et al. 2021). Pathiratna et al. (1990) also observed no increased growth or P uptake by inoculated AMF with the presence of apatite in soil of Sri Lanka, while the growth has increased considerably without soil added apatite.

Kodithuwakku et al. (2016) and Mala et al. (2010) found the application of the AMF into nursery plants of black pepper (Piper nigrum L.) was given a significant impact on growth parameters, particularly rooting and root growth. Jayaratne et al. (1984) who have tested the effect of vesicular-arbuscular mycorrhizae on seedlings of Hevea and Pueraria phaseoloides in Sri Lanka, observed that there was a slight growth response of Hevea when inoculated with Gigaspora margarita in sterile soil, while the uptake of nutrients by mycorrhizal Hevea plants were not significantly different. However, mycorrhizal $P$. phaseoloides were shown a higher nutrient uptake than the non-mycorrhizal plants. Dahanayake \& Alawathugoda (2015) observed significantly higher pod numbers in soybean plants provided with AMF. Further, Madhushan et al. (2020) revealed that yield of lowland rice (Oryza sativa) in dry zone, Sri Lanka could be enhanced by the periodical application of indigenous AMF inoculum, along with both conventional and organic nutrient management.

\section{Disease resistance}

Several studies have proven that AMF increase plant's disease resistance against soilborne plant pathogens (Harrier \& Watson 2004, Siddiqui \& Pichtel 2008). However, the effectiveness of bio-control achieved by AMF is dependent on the AMF species involved, the substrate and host plant. Also, the protection given by AMF is not effective against all the pathogens and regulated by soil and other environmental conditions (Akhtar \& Siddiqui 2008). Studies have shown AMF capable of protect plants against pathogens through various mechanisms including altering root growth and morphology, creating histopathological changes in the host root, making physiological and biochemical changes within the host, changing host nutrition, modifying mycorrhizosphere which affects microbial populations, competing for colonization sites and foods, activating defense mechanisms, and parasitism on nematodes (Siddiqui \& Mahmood 1995, Akhtar \& Siddiqui 2008, Bagyaraj 2014).

Jayaratna et al. (1986) found that AMF (Gigaspora margarita) able to inhibit the white root disease in Hevea and Pueraria phaseoloides caused by the fungus Rigidoporus lignosus. Root infection of $R$. lignosus in Hevea seedlings was inhibited by G. margarita up to 240 days and it was about up to 60 days in $P$. phaseoloides, and thereafter the inhibition has been ceased. Further, they suggested that such tolerance to white root disease caused by G. margarita could be due to the enhanced uptake of $\mathrm{P}$ and other minerals, antibiotic production and/or stimulation of root phytoalexin production.

\section{Heavy metal tolerance and remediation from soil}

Arbuscular mycorrhizal fungi are also capable of alleviate metal toxicity of the host plants by restricting metal translocation from root to shoot (Leyval et al. 1997). The restricted translocation is mainly due to the adsorption or compartmentation within mycorrhizal fungal vacuoles (Turnau et al. 1993, Leyval et al. 1997, Joner et al. 2000). The mechanisms of surface adsorption involve ionexchange, complexation, crystallization and precipitation of metals on the cell wall components of 
extra- and intra-radical hyphae (e.g. chitin, melanin and cellulose derivatives) or extracellular slime, which may reduce the intracellular accumulation of heavy metals and their effects on the processes of cytoplasm (Turnau et al. 1993, Galli et al. 1994, Denny \& Ridge 1995). The mechanisms within fungal cells involve metal ion chelation by ligands like polyphosphates, metallothioneins and/or compartmentation within vacuoles (Turnau et al. 1993, Kaldorf et al. 1999, Joner et al. 2000). Therefore, AMF may increase plant establishment and survival in heavy metal polluted sites and could be used as a complement to immobilization strategies (Leyval et al. 2002). Also, since AMF penetrate into extremely small pores in soil, access contaminants and could be transported into the plant (Hutchinson et al. 2003, Siddiqui \& Pichtel 2008). Therefore, in some cases mycorrhizal plants exhibit enhanced heavy metal uptake and root-to-shoot transportation (Siddiqui \& Pichtel 2008). Hence AMF are beneficial in phytoremediation: the engineered use of green plants to remediate polluted sites. Therefore, inoculation of AMF with metal hyperaccumulating plants may enhance the potential of phytoremediation and ultimately increases the agricultural production due to the alleviated soil stress (Siddiqui \& Pichtel 2008).

Sri Lankan farmers commonly practice conventional agriculture with using synthetic fertilizer, herbicides and pesticides. However, the continuous use of such agro-chemicals has resulted in heavy metal contamination in Sri Lankan agricultural soils. It has been found that the superphosphate fertilizer abundant in toxic metals and metalloids such as $\mathrm{Cd}, \mathrm{Pb}, \mathrm{Hg}, \mathrm{U}, \mathrm{Cr}$ and as (van Kauwenbergh 2002, Dissanayake \& Chandrajith 2009). Such added Cd has been identified as a probable cause for chronic kidney disease of unknown aetiology (CKDu) which was reported during the last decade in farmers live in North Central Province of Sri Lanka (Nanayakkara et al. 2012, Jayasumana et al. 2015). Implementing phytoremediation by intercropping of mycorrhizal plants would be a great solution to reduce accumulation of toxic metals in crop plants and subsequent movement through food chains.

Water hyacinth (Eichhornia crassipes) has been identified as a phytoremediative aquatic plant. Gunathilakae et al. (2018) demonstrated that uptake of Cd could be enhanced by inoculating AMF to water hyacinth plants. They observed the highest shoot and root Cd concentrations in AMF inoculated plants. Further, both soil and water Cd concentrations were reduced in AMF inoculated treatments indicating that AMF could be used along with hyper-accumulative plants to clean up contaminated soil and water in Sri Lanka.

\section{Drought tolerance}

AMF enhance the ability of plants to tolerate detrimental effects caused by the water stress (Davies et al. 2002). The protection of host plants by AMF symbiosis has been explained by proposing several mechanisms, such as changes in phytohormones, enhanced leaf gas exchange and photosynthetic rate, direct hyphal uptake of water from the soil and transfer to the host plant, enhanced activity of enzymes engaged in anti-oxidant defence, assimilation of nitrates, enhanced uptake of water through improved root hydraulic conductivity, osmotic adjustment, and changes in elasticity of cell-wall (Quilambo 2003). However, AMF become ineffective in more severe drought conditions, when soil water potential ranged from -1.5 to $-2.0 \mathrm{MPa}$ hence, they can only alleviate moderate drought stresses in wheat (Bryla \& Duniway 1997). Drought is the most frequent natural disaster affecting both crop production and livelihood of Sri Lanka (Chithranayana 2008), and it has been estimated that drought damages over half of the agricultural crops in Sri Lanka (Prasanna 2018). Since AMF have the capacity to make plants tolerant for water scarce, could be used for mitigate such crop losses. Pavithra \& Yapa (2018) have showed the adding of AMF can increase the growth and yield of soybean (Glycine max L.) in dry zone of Sri Lanka. under water stressed conditions. As per their observations, the soil moisture content is higher in AMF inoculated treatments which indicates the AMF capable of increasing soil moisture. Further they addressed the observed drought tolerance is due to the plant responses such as osmotic adjustment.

\section{Interactions of AMF and other soil microorganisms}

The region of surrounding soil, influenced by AMF hyphae termed as the mycorrhizosphere 
(Linderman 1991). Generally, the volume of mycorrhizosphere soil is larger than the volume of rhizosphere soil, as AMF modify the host root morphology (Linderman 1991). Also, root exudation in the mycorrhizosphere is different than in the rhizosphere, as AMF alter root exudation by qualitatively and quantitatively (Leyval \& Berthelin 1993). Therefore, it is clear that the soil microbial communities in the mycorrhizosphere differ from those in the rhizosphere of nonmycorrhizal plants and bulk soil (Garbaye 1991). The interaction of AMF with the mycorhizospheric microorganisms could be either beneficial or detrimental to both organisms.

Arbuscular mycorrhizal fungi interact with several beneficial microorganisms and consequently the plant growth would be increased. Samarakoon \& Yapa (2019) reported that the application of AMF and Bradyrhizobium japonicum together with organic manure could enhance the growth and seed nutrient quality of soybean (Glycine max L.). Also, Alawathugoda \& Dahanayake (2014) and Dahanayake \& Alawathugoda $(2015,2016)$ observed that soil treated with AMF, without inorganic fertilizer has given the highest soil microbial activity (emitted $\mathrm{CO}_{2} \mathrm{mg} / \mathrm{kg}$ of soil) in soybean and rice (Oryza sativa). Further, they have reported that there were larger and more numbers of root nodules presented in mycorrhizal treatments. Jayaratne et al. (1984) also found significantly higher root nodule formation in mycorrhizal P. phaseoloides in Sri Lanka.

Jayawardhane \& Yapa (2018) who studied on the microbial solubilization of Eppawala Rock Phosphate (ERP) revealed that application of AMF and Pseudomonas fluorescens together with biochar has the potential to solubilize ERP in short term applications. Also, Pathiratna et al. (1990) reported that presence of AMF could further enhance the multiplication of $\mathrm{P}$ dissolving bacteria, which was also stimulated by apatite (ERP). However, Kodithuwakku et al. (2016) have reported that the combined application of Trichoderma spp. and Pseudomonas fluorescens along with the AMF, Funneliformis mosseae (formally Glomus mosseae) in nursery plants of black pepper (Piper nigrum L.) grown in Sri Lanka, was not shown a significant impact on growth, compared to the non- AMF added plants.

\section{Arbuscular mycorrhizal fungi in sustainable forest management}

Arbuscular mycorrhizal fungi are known to enhance the growth of mature forest plants (Treseder 2013) and survival of seedlings (Davidson 2015). Gamage et al. (2004) have assessed the response of plant growth and AMF colonization in seedlings of four Syzygium spp. at different light and soil nutrient levels. The results showed were suggested that AMF colonization and plant growth will be highest under the canopy openings large enough to capture direct sunlight in $\mathrm{P}$ rich soils in Sri Lanka.

Gunadasa et al. (2012) found that AMF could be used for the conservation and sustainable management of montane forests in Sri Lanka, during a preliminary study which was undertaken to investigate the effect of AMF on forest dieback in Hortain Plains. According to their findings, Syzygium rotundifolium saplings shown higher AMF colonization and total $\mathrm{P}$ contents, and reduced foliar heavy metal contents by the application of native AMF inoculum together with compost, indicating that AMF are able to enhance the potential of regeneration of native saplings in forest dieback areas.

Natural and man-made disturbances in forest ecosystems in Sri Lanka resulted disruptions in prevailing soil AMF abundance and diversity. Edirisinghe \& Madawala (2017) investigated that the change of AMF dynamics of a series of land use types viz., a mature forest, a regenerating Eucalyptus plantation and an untouched Eucalyptus plantation which represent a chronological sequence of events of a land conversion, from a mature forest to a Eucalyptus plantation. Mature forest has showed the highest diversity index, and significantly higher average spore counts and root colonization percentages than the other land use types, indicating that change of land use has drastically reduced their composition and abundance.

Also, Mafaziya \& Madawala (2015) who studied the abundance and richness of AMF in natural and semi natural land use types of upper Hantana area, Sri Lanka, reported similar observations: highest spore abundance in natural forest patch followed by restored pine stand, degraded grassland and Paraserianthes stand. However, restoration with pine has been impacted 
positively on the soil micro biota within a relatively short period of time, because AMF richness in restored pine stand was similar to that of natural forest patch (Table 1).

Similar to the above studies, Silva \& Yapa (2010) observed reduced root colonization levels caused by soil disturbances in medicinal plants at Mihintale Sanctuary in Sri Lanka (Table 2). Also, they suggested the composition of AMF community could be used as a determinant of plant response for the disturbance of soil.

Table 2 Root colonization percentages of medicinal plants in disturbed and un-disturbed sites at Mihintale Sanctuary in Sri Lanka. Adapted from Silva \& Yapa (2010)

\begin{tabular}{|c|c|c|}
\hline \multirow{2}{*}{ Plant } & \multicolumn{2}{|c|}{ Degree of colonization (\%) } \\
\hline & Disturbed & Non-disturbed \\
\hline Adathoda (Justica adhathoda) & 4.16 & 17.06 \\
\hline Eth adi (Elephantopus scaber) & 5.01 & 86.25 \\
\hline Gatapichcha (Jasminum sambac) & 11.33 & 14.66 \\
\hline Hathawariya (Asparagus racemosus) & 80.00 & 89.74 \\
\hline Heenundupiyaliya (Desmodium triflorum) & 12.34 & 14.70 \\
\hline Iramusu (Hemidesmus indicus) & 4.50 & 10.52 \\
\hline Katuelbatu (Solanum xanthocarpum) & 6.25 & 7.89 \\
\hline Kohomba (Azadirachta indica) & 18.82 & 24.29 \\
\hline Nilkatarolu (Clitoria ternatea) & 11.83 & 59.92 \\
\hline Ranawara (Cassia auriculata) & 18.75 & 35.04 \\
\hline
\end{tabular}

Invasion by exotic plants is a major threat of natural forest ecosystems, as they cause decline in native plant species. The invaded plants alter not only the above ground vegetation but also the composition and functions of soil microbiota as well (van der Putten et al. 2007). Madawala (2014) who worked on the impacts of invasive species on AMF abundance and diversity and found that AMF abundance in Knuckles Forest conservation area in Sri Lanka, which is dominated by Cymbopogon, has increased through the invasion of Austroeupatorium inulifolium. Further, such areas were capable of harbouring higher AMF populations than in multi-species forests may perhaps due to a greater number of mycorrhizal forbs.

Also, Mafaziya et al. (2019) evaluated the impact of over-abundance of native bamboo species, Bambusa bambos (L.) Voss. on the AMF communities in tropical moist evergreen forests in Sri Lanka. The results showed that the AMF community structure was not altered by the overabundance of $B$. bambos indicating the ability of AMF to withstand the dominance of a single species. Further, results were highlighted that there is a potential of enhancing AMF abundance and richness following the dominance of B. bambos.

\section{Arbuscular mycorrhizal fungi inoculum production}

Agricultural crop production involves a range of management practices which can influence on AM association. The influence may be either direct, by damaging or killing of AMF or indirect, by creating favourable or unfavourable conditions to AMF (Gosling et al. 2006). However, in general, high -input agricultural practices have a negative impact on the AMF associations in agricultural soils, particularly poor in species diversity (Wanninayake et al. 2021). Therefore, soil introduction of efficient indigenous AMF species is important (Yapa et al. 2020). Since AMF are obligate symbionts, culturing them on artificial synthetic media has failed or little in success. Therefore, growing of AMF could only be done with the aid of host plant roots (Bagyaraj 2014). Trapping of AMF using highly susceptible host plants grown in sterilized soil, which is known as 'Trap culture' is the frequently used technique for mass production of AMF (Bagyaraj 2014, Sadhana 2014, Yapa et al. 2020). The inoculum can be produced by using spores, hyphae, infected root pieces and infested soil or rooting medium obtained from pot cultures, either as a mixture or separately (Yapa et al. 2020). 
Jayaratne \& Siriwardene (2000) have developed a very simple and economical method for the commercial production of AMF inoculum. Here they grown Pueraria phaseoloides seedlings preinoculated with Acaulospora spinosa in large pots filled with a medium contained fine coir dust and finely ground rice husks at 1:1 ratio. After 3-4 months, the shoots at collar region were cut-off and the contents of pots including chopped root fragments and rhizospheric soil were mixed thoroughly, air dried to attain about $40 \%$ moisture content, and packed in polythene bags. These inoculums were stored in refrigerator $\left(8-10^{\circ} \mathrm{C}\right)$ and have observed more than $90 \%$ of root length colonization of 4 months old Pueraria roots even after 18 months of storage.

Mala et al. (2010) have produced an AMF (Glomus mosseae) inoculum using Sorghum (Sorghum bicolor L.) in Sri Lanka for the application of black pepper rooted cuttings. The inoculum was contained spores, fungal structures with sorghum roots and rhizospheric soil.

\section{Conclusion}

A number of successful researches on different species of AMF inoculations were published on in the context of Sri Lankan agriculture. However, there is a huge potential of using AMF yet to be touched. Studies should be done on the screening of indigenous AMF species which are most efficient for particular crops, mass production of them by using low- cost methods, and commercialize or distribute among the farmers with proper awareness. Use of AMF for rice (Oryza sativa) cultivation should also be encouraged since it is the staple food of Sri Lanka and there are several successful studies with rice in the world context. Further, there are least investigations on the alleviation of biotic and abiotic stresses in crops by using AMF. Information on the effects of agronomic and cultural practices of crop cultivation on AMF both in short and long run also poorly addressed in Sri Lankan scenario. Also, studies on the potential enemies of AMF and competition of introduced AMF with native microorganisms also intensified as they affect directly on the success of the AMF inoculation.

\section{Competing interest disclaimer:}

Authors have declared that no competing interests exist.

\section{Acknowledgement}

Financial assistance given by World Bank Group through the project, Accelerating Higher Education Expansion and Development Operation (AHEAD), DOR, Grant No 79, Rajarata University of Sri Lanka, is highly appreciated.

\section{References}

Akhtar MS, Siddiqui ZA. 2008 - Arbuscular mycorrhizal fungi as potential bioprotectants against plant pathogens. In Mycorrhizae: Sustainable agriculture and forestry. Springer, Dordrecht.

Alawathugoda CJ, Dahanayake N. 2014 - Effects of mycorrhizae as a substitute for inorganic fertilizer on growth and yield of tomato (Lycopersicon esculentum L.) and soybean (Glycine $\max$ L.), and soil microbial activity. Tropical Agricultural Research and Extension. 16, 107112.

Bagyaraj DJ. 2014 - Mycorrhizal fungi. Proceedings of the Indian National Science Academy 80, $415-428$.

Balasuriya A, Arulpragasam PV, Ratnayake RMA. 1991 - Mycorrhiza in tea. Tea Bulletin (Sri Lanka).

Balasuriya A, Wimaladasa GD, Ratnayake RMA. 2000 - Effect of application of NPK fertilizers on the natural incidence of vesicular-arbuscular mycorrhiza in the rhizosphere soils and feeder roots of tea (Camellia sinensis). Sri Lanka Journal of Tea Science 66, 61-66.

Brady NC, Weil RR. 2008 - The soils around us. The nature and properties of soils, 14th ed Pearson Prentice Hall, New Jersey and Ohio. 
Brundrett M. 2004 - Diversity and classification of mycorrhizal associations. Biological Reviews 79, 473-495.

Brundrett MC. 2009 - Mycorrhizal associations and other means of nutrition of vascular plants: understanding the global diversity of host plants by resolving conflicting information and developing reliable means of diagnosis. Plant and Soil 320, 37-77.

Bryla DR, Duniway JM. 1997 - Effects of mycorrhizal infection on drought tolerance and recovery in safflower and wheat. Plant and soil 197, 95-103.

Chithranayana D. 2008 - Identification of drought prone agro-ecological regions in Sri Lanka. Journal of National Science Foundation Sri Lanka 36, 117-123.

Dahanayake D, Alawathugoda CJ. 2015 - Effect of mycorrhizae, NPK and compost on vegetative and reproductive parameters of soybean (Glycine max L). International Journal of Science and Research 5, 342-46.

Dahanayake N. Alawathugoda CJ. 2016 - Influence of Mycorrhizae and Inorganic Fertilizer on Plant Growth and Yield Components of Two Sri Lankan Traditional Rice Accessions (Oryza sativa L). Tropical Agricultural Research and Extension 19, 260-263.

Davidson BE. 2015 - Consequences of pre-inoculation with native arbuscular mycorrhizae on root colonization and survival of Wyoming big sagebrush (Artemisia tridentata ssp. wyomingensis) seedlings after transplanting. PhD thesis, Boise State University, Idaho, USA.

Davies Jr FT, Olalde-Portugal V, Aguilera-Gomez L, Alvarado MJ et al. 2002 - Alleviation of drought stress of Chile ancho pepper (Capsicum annuum L. cv. San Luis) with arbuscular mycorrhiza indigenous to Mexico. Scientia Horticulturae. 92, 347-359.

Denny HJ, Ridge I. 1995 - Fungal slime and its role in the mycorrhizal amelioration of zinc toxicity to higher plants. New Phytologist. 130, 251-257.

Dissanayake CB, Chandrajith R. 2009 - Phosphate mineral fertilizers, trace metals and human health - A review. Journal of the National Science Foundation of Sri Lanka. 37, 153-165.

Douds Jr DD, Millner PD. 1999 - Biodiversity of arbuscular mycorrhizal fungi in agroecosystems. Agriculture, ecosystem and environment. 74, 77-93.

Edirisinghe C, Madawala S. 2017 - Arbuscular mycorrhizal fungal dynamics following change of land use from mature forest to Eucalyptus plantation. Journal of National Science Foundation Sri Lanka. 45, 321-328.

Entry JA, Watrud LS, Reeves M. 1999 - Accumulation of 137Cs and 90Sr from contaminated soil by three grass species inoculated with mycorrhizal fungi. Environmental Pollution 104, 449457.

Fortin JA, Plenchette C, Piché Y. 2009 - Mycorrhizas: The new green revolution. Éditions MultiMondes.

Galli U, Schüepp H, Brunold C. 1994 - Heavy metal binding by mycorrhizal fungi. Physiologia Plantarum. 92, 364-368.

Gamage HK, Singhakumara BMP, Ashton MS. 2004 - Effects of light and fertilization on arbuscular mycorrhizal colonization and growth of tropical rain-forest Syzygium tree seedlings. Journal of Tropical Ecology 20, 525-34.

Garbaye J. 1991 - Biological interactions in the mycorrhizosphere. Experimentia. 47, 370-375.

Goltapeh EM, Danesh YR, Prasad R, Varma A. 2008 - Mycorrhizal fungi: What we know and what should we know? In Mycorrhiza. Springer, Berlin, Heidelberg.

Gosling P, Hodge A, Goodlass G, Bending GD. 2006 - Arbuscular mycorrhizal fungi and organic farming. Agriculture, Ecosystems and Environment 113, 17-35.

Gregory PJ. 2006 - Plant roots: Growth, activity and interaction with soils. Blackwell Publishing: Oxford, UK.

Gunadasa SG, Yapa PI, Nissanka SP, Perera SP. 2012 - Remediation of Pb/Cd contaminated forest soils by compost and mycorrhizae: will it be a solution to the forest dieback. In International Conference on Future Environment and Energy. 28, 139-44. 
Gunathilakae N, Yapa PN, Hettiarachchi R. 2018 - Effect of arbuscular mycorrhizal fungi on the cadmium phytoremediation potential of Eichhornia crassipes (Mart.) Solms. Groundwater and Sustainable Development 7, 477-82.

Halim NA. 2009 - Effects of using enhanced biofertilizer containing N-fixer bacteria on patchouli growth (Doctoral dissertation, UMP).

Hamel C, Plenchette C. 2007 - Extraradical arbuscular mycorrhizal mycelia: shadowy figures in the soil. Mycorrhizae in crop production: applying knowledge. Haworth, Binghampton.

Harrier LA, Watson CA. 2004 - The potential role of arbuscular mycorrhizal (AM) fungi in the bioprotection of plants against soil-borne pathogens in organic and/or other sustainable farming systems. Pest Management Science 60, 149-157.

Harrison MJ. 2005 - Signaling in the arbuscular mycorrhizal symbiosis. Annual Review of Microbiology 59, 19-42.

Hayman DS. 1983 - The physiology of vesicular-arbuscular endomycorrhizal symbiosis. Canadian Journal of Botany 61, 944-963.

Hutchinson SL, Schwab AP, Banks MK. 2003 - Biodegradation of petroleum hydrocarbons in the rhizosphere. Phytoremediation: transformation and control of contaminants.

Jayaratna R, Liyanage ADS, Pahalawattaarachchi W. 1986 - Effect of VA mycorrhizae (Gigaspora margarita) on white root disease resistance in Pueraria phaseoloides and Hevea brasiliensis seedlings. Journal of Rubber Research Institute of Sri Lanka 65, 22-31.

Jayaratne AHR, Peries OS, Waidyanatha UDS. 1984 - Effect of vesicular-arbuscular mycorrhizae on seedlings of Hevea and Pueraria phaseoloides. Journal of Rubber Research Institute Sri Lanka 62, 75-84.

Jayaratne AHR, Siriwardene D. 2000 - Arbuscular mycorrhizal inoculum production for commercial use. Tropical Agricultural Research and Extension 3, 137-40.

Jayasumana C, Fonseka S, Fernando S, Jayalath K et al. 2015 - Phosphate fertilizer is a main source of arsenic in areas affected with chronic kidney disease of unknown etiology in Sri Lanka. Springer Plus. 4, 90.

Jayawardhane S, Yapa PN. 2018 - Potential of microbial solubilization of rock phosphate for use in sustainable agriculture: Does biochar application enhance microbial solubilization. Journal of Advances in Microbiology 8, 1-8.

Johnson NC, Gehring CA. 2007 - Mycorrhizas: symbiotic mediators of rhizosphere and ecosystem processes. In the Rhizosphere. Academic Press.

Joner EJ, Briones R, Leyval C. 2000 - Metal-binding capacity of arbuscular mycorrhizal mycelium. Plant and Soil. 226, 227-234.

Kaldorf M, Kuhn AJ, Schröder WH, Hildebrandt U, Bothe H. 1999 - Selective element deposits in maize colonized by a heavy metal tolerance conferring arbuscular mycorrhizal fungus. Journal of Plant Physiology. 154, 718-728.

Karunasinghe TG, Fernando WC, Jayasekera LR. 2009 - The effect of poultry manure and inorganic fertilizer on the arbuscular mycorrhiza in coconut. Journal of National Science Foundation Sri Lanka. 37, 277-279.

Kodithuwakku RD, Wijekoon WMRWB, Kumari IS, De Silva DPP. 2016 - Efficacy of single and combined application of Trichoderma spp. and Pseudomonas fluorescens along with biofertilizer (Arbuscular mycorrhizae) on growth of nursery plants of black pepper (Piper nigrum L.). Sri Lanka Journal of Food and Agriculture 2, 69-72.

Lakmali JPD, Yapa PN, Sadaruwan MKKD. 2019 - Role of the vetiver (Chrysopogon zizanioides L.) and arbuscular mycorrhizal fungi on soil quality improvement in Pinus plantation soil. In proceedings of International Research Symposium on Pure and Applied Sciences, Faculty of Science, University of Kelaniya, Sri Lanka. 25 ${ }^{\text {th }}$ October 2019.

Leyval C, Berthelin J. 1993 - Rhizodeposition and net release of soluble organic compounds by pine and beech seedlings inoculated with rhizobacteria and ectomycorrhizal fungi. Biology and Fertility of Soils. 15, 259-267. 
Leyval C, Joner EJ, Del Val C, Haselwandter K. 2002 - Potential of arbuscular mycorrhizal fungi for bioremediation. In Mycorrhizal technology in agriculture. Birkhäuser, Basel.

Leyval C, Turnau K, Haselwandter K. 1997 - Effect of heavy metal pollution on mycorrhizal colonization and function: physiological, ecological and applied aspects. Mycorrhiza. 7, 139153.

Linderman RG. 1991 - Mycorrhizal interactions in the rhizosphere. In The rhizosphere and plant growth. Springer, Dordrecht.

Madawala HMSP. 2014 - Austroeupatorium inulifolium invasion increases arbuscular mycorrhizal abundance in Cymbopogon-dominated grasslands in Knuckles Conservation Area. Journal of National Science Foundation Sri Lanka. 42, 361-64.

Madhushan KWA, Yapa PN, Dissanayake DMD, Priyadarshani TDC. 2020 - Effect of arbuscular mycorrhizal fungi on growth and yield of lowland rice (Oryza sativa L.) intercropped with vetiver grass (Chrysopogon zizanioides L.). In $12^{\text {th }}$ Annual Symposium Proceedings. Faculty of Agriculture, Rajarata University of Sri Lanka, Anuradhapura.

Mafaziya F, Madawala S. 2015 - Abundance, richness and root colonization of arbuscular mycorrhizal fungi in natural and semi-natural land use types at upper Hantana. Ceylon Journal of Science (Biological Sciences) 44, 25-34.

Mafaziya F, Wijewickrama T, Madawala HMSP. 2019 - Does over-dominance of Bambusa bambos (L.) Voss. alter abundance and richness of Arbuscular Mycorrhizal fungal community in forests? Ceylon Journal of Science 48, 51-59.

Mala WJ, Kumari S, Sumanasena HA, Nanayakkara CM. 2010 - Effective spore density of Glomus mosseae, arbuscular mycorrhiza (AM), for inoculation of rooted cuttings of Black Pepper (Piper nigrum L.). Tropical Agricultural Research. 21, 189-197.

Marshall JD, Perry DA. 1987 - Basal and maintenance respiration of mycorrhizal and nonmycorrhizal root systems of conifers. Canadian Journal of Forest Research 17, 872-877.

Martin F, Perotto S, Bonfante P. 2007 - Mycorrhizal fungi: a fungal community at the interface between soil and roots. The rhizosphere: Biochemistry and organic substances at the soilplant interface. Marcel Dekker, New York.

Morton JB, Benny GL. 1990 - Revised classification of arbuscular mycorrhizal fungi (Zygomycetes): a new order, Glomales, two new suborders, Glomineae and Gigasporineae, and two new families, Acaulosporaceae and Gigasporaceae, with an emendation of Glomaceae. Mycotaxon. 37, 471-491.

Morton JB, Bentivenga SP. 1994 - Levels of diversity in endomycorrhizal fungi (Glomales, Zygomycetes) and their role in defining taxonomic and non-taxonomic groups. Plant and soil. $159,47$.

Morton JB, Msiska Z. 2010 - Phylogenies from genetic and morphological characters do not support a revision of Gigasporaceae (Glomeromycota) into four families and five genera. Mycorrhiza. 20, 483-496.

Muchovej RM. 2001 - Importance of mycorrhizae for agriculture crops. University of Florida Extension Service. Pamphlet SS-AGR-170.

Nanayakkara S, Komiya T, Ratnatunga N, Senevirathna ST et al. 2012 - Tubulointerstitial damage as the major pathological lesion in endemic chronic kidney disease among farmers in North Central Province of Sri Lanka. Environmental Health and Preventive Medicine. 17, 213-221.

Oehl F, de Souza FA, Sieverding E. 2008 - Revision of Scutellospora and description of five new genera and three new families in the arbuscular mycorrhiza-forming Glomeromycetes. Mycotaxon 106, 311-360.

Pathiratna LSS, Waidyanatha UDS, Peiris OS. 1990 - Utilization of phosphorus from apatite and growth of plants inoculated with vesicular arbuscular mycorrhiza and phosphate dissolving bacteria. Journal of Rubber Research Institute of Sri Lanka. 70, 35-43.

Pavithra D, Yapa PN. 2018 - Arbuscular mycorrhizal fungi inoculation enhances drought stress tolerance of plants. Groundwater and Sustainable Development 7, 490-494. 
Peterson RL, Massicotte HB, Melville LH. 2004 - Mycorrhizas: anatomy and cell biology. NRC Research Press.

Prasanna RPIR. 2018 - Economic costs of drought and farmers' adaptation strategies: evidence from Sri Lanka. Sri Lanka Journal of Economic Research 5(2), 61-79.

Qin M, Zhang Q, Pan J, Jiang S et al. 2020 - Effect of arbuscular mycorrhizal fungi on soil enzyme activity is coupled with increased plant biomass. European Journal of Soil Science 71, 84-92.

Quilambo OA. 2003 - The vesicular-arbuscular mycorrhizal symbiosis. African Journal of Biotechnology 2, 539-546.

Rajapaksha RMCP, Ranasinghe RASW. 2007 - Arbuscular mycorrhizal fungi associations in exotic vegetables grown on Ultisols of Nuwara Eliya. Journal of Soil Science Society of Sri Lanka. 19, 1-8.

Sadhana B. 2014 - Arbuscular mycorrhizal fungi (AMF) as a biofertilizer-a review. International Journal of Current Microbiology and Applied Sciences 3, 384-400.

Samarakoon D, Yapa N. 2019 - Growth, yield and seed nutrient quality of soybean (Glycine max L.) as affected by organic, biofertilizer and synthetic fertilizer application. South Asian Journal of Research in Microbiology 5, 1-6.

Schüßler A, Schwarzott D, Walker C. 2001 - A new fungal phylum, the Glomeromycota: phylogeny and evolution. Mycological Research 105, 1413-1421.

Seneviratne G, Kulasooriya SA. 1994 - Fate of applied N in traditional, modern, and conservation farming systems of lowland rice in Sri Lanka. International Rice Research Notes (Philippines).

Siddiqui ZA, Mahmood I. 1995 - Role of plant symbionts in nematode management: a review. Bioresource Technology 54, 217-226.

Siddiqui ZA, Pichtel J. 2008 - Mycorrhizae: an overview. In: Mycorrhizae: Sustainable Agriculture and Forestry. Springer, Dordrecht.

Silva KSN, Yapa PN. 2010 - The status of vesicular arbuscular mycorrhizal associations with medicinal plants in Mihintale Sanctuary. In: Proceedings of the 15th International Forestry and Environment Symposium. University of Sri Jayawardanapura, Sri Lanka. $26^{\text {th }}-27^{\text {th }}$ November 2010.

Smith SE, Read DJ. 2010 - Mycorrhizal symbiosis. Academic press.

Strullu DG, Chamel A, Eloy JF, Gourret JP. 1983 - Ultrastructure and analysis, by laser probe mass spectrography, of the mineral composition of the vesicles of trifolium pra tense endomycorrhizas. New Phytologist 94, 81-88.

Toro M, Azcón R, Barea JM. 1998 - The use of isotopic dilution techniques to evaluate the interactive effects of Rhizobium genotype, mycorrhizal fungi, phosphate-solubilizing rhizobacteria and rock phosphate on nitrogen and phosphorus acquisition by Medicago sativa. The New Phytologist 138, 265-273.

Turnau K, Kottke I, Oberwinkler F. 1993 - Element localization in mycorrhizal roots of Pteridium aquilinum (L.) Kuhn collected from experimental plots treated with cadmium dust. New Phytologist 123, 313-324.

Treseder KK. 2013 - The extent of mycorrhizal colonization of roots and its influence on plant growth and phosphorus content. Plant and Soil 371, 1-13.

van der Heijden MG, Martin FM, Selosse MA, Sanders IR. 2015 - Mycorrhizal ecology and evolution: the past, the present, and the future. New Phytologist 205, 1406-1423.

van der Putten WH, Klironomos JN, Wardle DA. 2007 - Microbial ecology of biological invasions. Multidisciplinary Journal of Microbial Ecology. 1, 28-37.

van Kauwenbergh SJ. 2002 - Cadmium content of phosphate rocks and fertilizers. International Fertilizer Industrial Association (IFA) Technical Conference, Chennai, India. P. 31.

Wang B, Qiu YL. 2006 - Phylogenetic distribution and evolution of mycorrhizas in land plants. Mycorrhiza 16, 299-363.

Wanninayake PCU, Malaviarachchi MAPWK, Hettiarachch RP, Yapa PN. 2021 - Different sources of phosphorus fertilizers and soil amendments affected the phosphorus and cadmium 
content in soil, roots and seeds of maize (Zea mays L.). Turkish Journal of Agriculture, Food Science and Technology 9, 640-645.

Wardle DA, Bardgett RD, Klironomos JN, Setälä H et al. 2004 - Ecological linkages between aboveground and belowground biota. Science 304, 1629-1633.

Weerawardena TE, Bandara WMSB. 2018 - Spore abundance and morphological root modifications of arbuscular mycorrhizal fungi-infected black pepper (Piper nigrum L) plants in reddish brown latosolic soil of Matale in Sri Lanka. Sri Lanka Journal of Food and Agriculture 4, 1-5.

Yapa PN, Sadaruwan MKKD, Duminda, DMS, Bamunuarachchige TC. 2020 - Effect of bacterial biofertilizers, native arbuscular mycorrhizal fungi and soil amendments on soil and grain phosphorus availability of flooded rice in dry zone, Sri Lanka. Vingnanam Journal of Science University of Jaffna, Sri Lanka 15, 10-21. 